\title{
Effects of electrocautery to provoke endovascular thermal injury ${ }^{1}$
}

\author{
Efeitos do eletrocautério para provocar lesão térmica endovascular
}

\author{
Fabio Henrique Rossi', Nilo Mitsuru Izukawa ${ }^{\mathrm{II}}$, Domingos Guerino Silva ${ }^{\mathrm{III}}$, Juliana Chen ${ }^{\mathrm{IV}}$, Akash Kuzhiparambil Prakasanv, \\ Mabel Moura Barros Zamorano ${ }^{\mathrm{VI}}$, Lílian Mary Silva ${ }^{\mathrm{VII}}$ \\ ${ }^{1}$ Research performed at the Department of Vascular Surgery and Experimental Surgery, Dante Pazzanese Cardiovascular Institute (IDPC), Sao Paulo, \\ Brazil. \\ ${ }^{\mathrm{I}} \mathrm{PhD}$, Vascular Surgeon, Department of Vascular Surgery, IDPC, Sao Paulo, Brazil. Responsible for conception, design and intellectual and scientific \\ content of the study. \\ II PhD, Director, Department of Vascular Surgery, IDPC, Sao Paulo, Brazil. Critical revision. \\ ${ }^{\text {III }} \mathrm{PhD}$, Vascular Surgeon, Department of Vascular Surgery, IDPC, Sao Paulo, Brazil. Critical revision. \\ ${ }^{\text {IV }}$ MD, Resident, Department of Vascular Surgery, IDPC, Sao Paulo, Brazil. Acquisition of data. \\ ${ }^{\vee}$ MD, Vascular Surgeon, Department of Vascular Surgery, IDPC, Sao Paulo, Brazil. Acquisition of data. \\ ${ }^{v 1} \mathrm{PhD}$, Director, Department of Pathology, IDPC, Sao Paulo, Brazil. Analysis and interpretation of data. \\ ${ }^{\text {VII }} \mathrm{PhD}$, Pathologist, Department of Pathology, IDPC, Sao Paulo, Brazil Analysis and interpretation of data.
}

\begin{abstract}
PURPOSE: To investigate the effects of a new electrocautery device to provoke endovascular venous thermal injury.

METHODS: An experimental endovascular electrocautery was placed inside eight ex-vivo bovine saphenous veins models. Each one was divided in eight segments and progressive intensities of electric energy liberated. The macroscopic and microscopic effects were analyzed.

RESULTS: Forty bovine saphenous veins segments were studied. The higher the electric energy applied the greater the nuclear picnosis and more intense the cytoplasmatic shrinkage and electrocoagulation effects.
\end{abstract}

CONCLUSION: The experimental endovascular electrocautery device demonstrated to be both capable of inducing the destruction of the intimal layers of the studied vein model and provoke endovascular thermal injury.

Key words: Varicose Veins. Endovascular Procedures. Therapeutics. Electrocoagulation.

\section{RESUMO}

OBJETIVO: Investigar os efeitos de um modelo experimental de eletrocautério em provocar lesão venosa térmica endovascular. MÉTODOS: O eletrocautério endovascular foi colocado dentro de oito modelos experimentais de veia safena bovina. Cada uma foi dividida em oito segmentos e intensidades progressivas de energia elétrica liberada. Os efeitos macroscópicos e microscópicos foram analisados.

RESULTADOS: Foram estudados quarenta segmentos de veia safena bovina. Quanto maior a energia elétrica aplicada pelo eletrocauterizador endovascular maiores foram as alteraçoes de picnose nuclear e mais intensa a retração citoplasmática observada. CONCLUSÃO: O eletrocautério endovascular experimental demonstrou ser capaz de induzir a destruição da camada íntima e provocar lesão térmica endovascular.

Descritores: Varizes. Procedimentos Endovasculares. Terapêutica. Eletrocoagulação. 


\section{Introduction}

Symptomatic varicose veins occur in approximately $15 \%$ of men and $25 \%$ of women and represent a progressive degenerative disease of the vein wall. They may be an important cause of loss of life quality and costs for the health system.

Treatment is traditionally accomplished through surgical saphenous vein stripping and tributary phlebectomy ${ }^{1}$. Endovascular therapy liberates thermal energy in the vein lumen causing destruction of its internal layers and interruption of the blood flow. Radiofrequency $^{2}$ and laser $^{3}$ thermal ablation are currently used and seem to be associated with reduced risk of complications, allowing patients to resume their everyday life faster. The cost involved is higher than in the conventional surgical treatment, which may limit its use $\mathrm{e}^{2-3}$.

Thermal energy for vein occlusion was already used in the ancient times. Ember or incandescent metals were applied in the external surface of vessels to interrupt hemorrhages. Such process is still employed by the modern surgeon to perform electrocoagulation of small caliber vases through the utilization of the electric scalpel. External varicose vein electrocoagulation treatment has been described in the past $\mathrm{t}^{4-8}$.

Our study addresses the effects of a new experimental electrocautery device to provoke endovascular thermal injury. With the assistance of a conventional electric scalpel, progressive intensities of electric energy and consequently of heat were liberated inside an ex-vivo bovine saphenous vein model, and its macro and microscopic consequences were verified.

\section{Methods}

The research was approved by the Institutional Ethic Committee for experimental studies.

The experimental model of the endovascular electrocautery is made up of four stainless steel threads united in its distal and proximal extremity by two rings of the same material. Its distal head threads when open come in contact with the vein intimal layer. Its high conformability and deformity power allows its introduction inside the conventional $6 \mathrm{~F}$ multipurpose catheter (Figure 1).

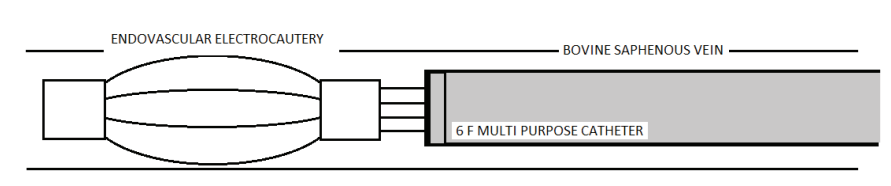

FIGURE 1 - Diagram of the experimental endovascular electrocautery inside a bovine saphenous vein model.

Eight ex-vivo bovine saphenous vein models were obtained from the front leg of freshly slaughtered cows.

After anterior skin flap surgical dissection and $V$. saphena lateralis and digitalis dorsalis commumunis exposure, five vein segments of similar longitudinal extensions were demarcated with the help of a ruler and a permanent ink pen.

The distal vein was cannulated with a $6 \mathrm{~F}$ multi-purpose conventional catheter over a $0.035^{\circ}$ guide-wire. The catheter was then positioned in the proximal vein segment and the guide-wire was substituted by the experimental electrocautery model (Figure 2).

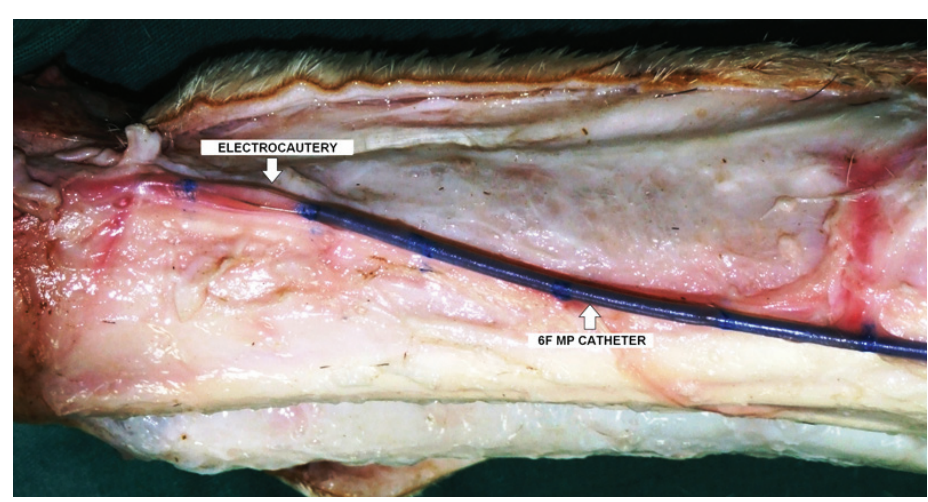

FIGURE 2 - Experimental electrocautery exposed at the proximal saphenous bovine vein. It was previous demarcated in five segments of similar longitudinal extensions.

Progressive intensities of electric energy were applied with a conventional electric scalpel (TRANSMAI BP-150; Transmai Hospitable Medical Equipament LTDA). The first segments were not submitted to electric power endovascular thermal liberation and were used as a control group.

The table below demonstrates the intensity of the electric power in Watts liberated for 5 seconds in the various previous demarked venous segments (Figure 3). 


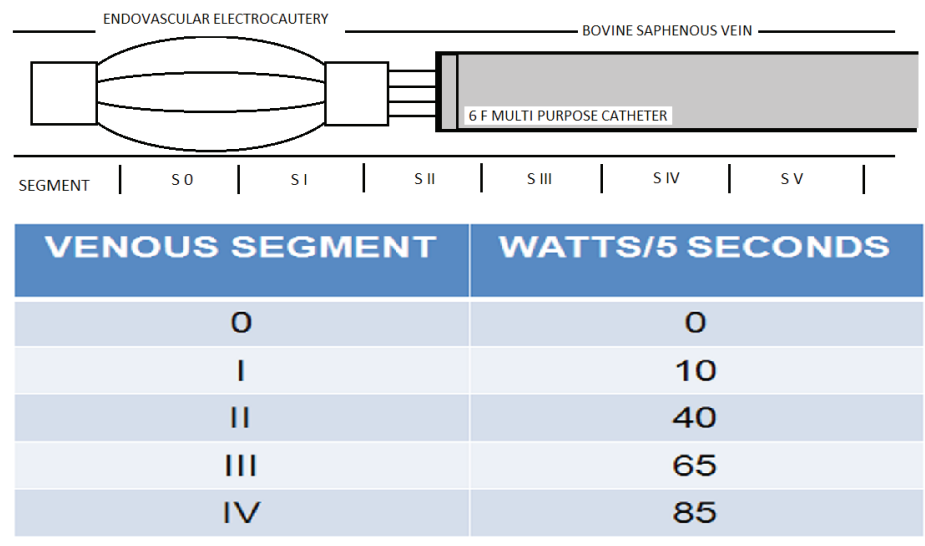

FIGURE 3 - Endovascular electric power energy liberated for five seconds inside each venous segment studied.

Eight successful experimental procedures were accomplished. After macroscopic external and internal vein wall inspection, central venous fragments were obtained and 40 microscopic histological studies accomplished.

\section{Results}

\section{Macroscopic aspects}

Macroscopic analysis clearly showed a decreased vase diameter in segments III and IV, in which the liberated thermal energy was higher.

The external palpation constantly verified a vessel wall indurations and thickening in these segments but not in I and II, in which the electrical energy applied was lower. After longitudinal vein opening, a whitish discoloration of the intimal layer was observed in the segments III and IV but not in I and II.

There was no macroscopic evidence of vein wall rupture or thermal damage of surrounding tissue layers.

\section{Microscopic aspects}

The different venous segments studied during the eight experiments presented a constant pattern of microscopic lesions on the vein wall tissue. The higher the electric energy applied the greater the nuclear picnosis and more intense the cytoplasmatic shrinkage, which suggest electrocoagulation endovascular venous thermal injury (Figure 4).

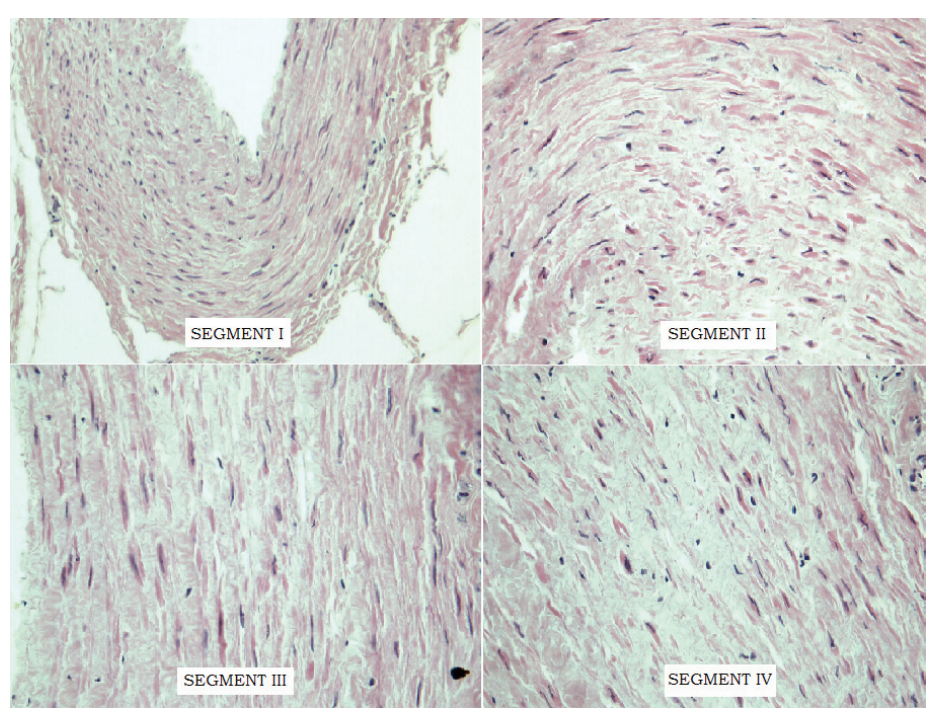

FIGURE 4 - Hematoxylin and eosin (HE) microscopic analysis findings: Segment I: HE 5X - Vascular wall with mild nuclear rarefaction. Segment II: HE $20 \mathrm{X}$ - Increase of cells with pyknotic nuclei and cytoplasm retraction. Segment III: HE 40 X - Microscopic field with most of cellular nuclei with pyknotic alteration and cytoplasm retraction. Segment IV: HE $40 \mathrm{X}$ - Microscopic field with almost all of pyknotic nuclei and cytoplasm retracted. No microscopic electrocoagulation effect was found in the adjacent layers.

No microscopic electrocoagulation effect was found in the adjacent layers in the accomplished experiments.

\section{Discussion}

The endovascular methods used at the present time in the treatment of varicose veins employ state-of-the art devices and highly expensive catheters.

The final objective is to perform total vein occlusion without causing thermal lesion in adjacent structures. Thus, whichever the method may be, the rigorous control of the liberated energy is essential to achieve high technical success and low complication rates.

It is notorious that endovascular thermal ablation provokes cellular destruction; however, it also leads to a cicatricial healing process. Such mechanism involves fibroblasts proliferation and collagen fibers remodeling and, as a final consequence, total vein occlusion ${ }^{2}$.

External electric cauterization of small bleeding vessels is a frequently performed procedure and easily accomplished with the help of the universally available electric scalpel. For this reason, we were interested in studying the use of this low cost 
technology in the endovascular electrocoagulation of varicose veins.

During this study, we used an ex-vivo bovine saphenous vein model previous used in the experimental evaluation of endoluminal thermal procedures ${ }^{9}$.

The endovascular electrocautery experimental device used demonstrated to be both macro and microscopically capable of inducing the destruction of the intimal layers of the vein model studied. The higher the electric power used the higher the degree of cellular destruction. This indicates the capacity of the method here described to obtain the selective destruction of the layers of a vessel. It also enabled the execution of all the procedures programmed without technical difficulties.

These characteristics may become reality the application of this electrocautery in the endovascular treatment of lower limb varicose veins.

Its compatibility with current peripheral endovascular catheterization equipment and techniques and lower cost may extend the application of the endovascular varicose vein thermal ablation to a larger number of patients.

\section{Conclusion}

The experimental endovascular electrocautery device demonstrated to be both macro and microscopically capable of inducing the destruction of the intimal layers of the studied vein model and provoke endovascular thermal injury.

\section{References}

1. Meissner MH, Eklof B, Gloviczki P, Lohr JM, Lurie F, Kistner R, Moneta G, Wakefield TW. Mapping the future: organizational, clinical, and research priorities in venous disease. J Vasc Surg. 2007;46 Suppl S:84S-93S.

2. Goldman MP. Closure of the greater saphenous vein with endoluminal radiofrequency thermal heating of the vein wall in combination with ambulatory phlebectomy: preliminary 6-month follow-up. Dermatol Surg. 2000;26:452-6.

3. Goldman MP, Mauricio M, Rao J. Intravascular 1320-nm laser closure of the great saphenous vein: a 6- to 12-month follow-up study. Dermatol Surg. 2004;30:1380-5.

4. Werner G, Alexander HA, Mc Phetrson HO. Electrofulguration. New surgical method for varicose veins. Minn Med. 1964;47:255-7.

5. Desbonnets G, Ampe J. Electrical treatment of varices by electrofulguration. J Sci Med Lille. 1968;86:261-3.

6. Di Maria G, Maouni A, Marioka Y, Favre M. Electrofulguration of varices, complementary period of stripping. Phlebologie. 1968;21:311-5.

7. Kordt KF. Electrofulguration of varices. Nord Med. 1970;84:1025.

8. Gradman WS. Venoscopic obliteration of variceal tributaries using monopolar electrocautery. Preliminary report. J Dermatol Surg Oncol. 1994;20:482-5.

9. Schmedt CG, Sroka R, Steckmeier S, Meissner OA, Babaryka G, Hunger K, Ruppert V, Sadeghi-Azandaryani M, Steckmeier BM. Investigation on radiofrequency and laser $(980 \mathrm{~nm})$ effects after endoluminal treatment of saphenous vein insufficiency in an ex-vivo model. Eur J Vasc Endovasc Surg. 2006;32:318-25.

\section{Correspondence:}

Fabio Henrique Rossi

Av Dante Pazzanese, 500

04012-180 São Paulo - SP Brasil

Tel: (55 11)4227-6658

vascular369@hotmail.com

Received: January 14, 2011

Review: March 17, 2011

Accepted: April 19, 2011

Conflict of interest: none

Financial source: Adib Jatene Foundation 